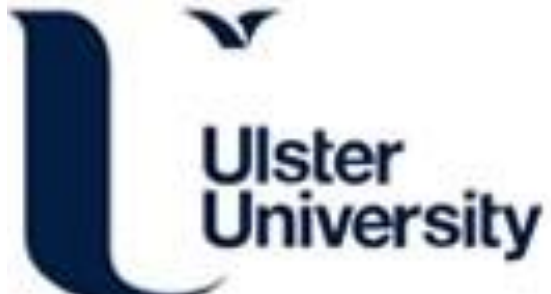

\section{Spatial variability in beach biogeomorphology in a tropical archipelago}

Gore, S., Cooper, A., Jackson, DWT., \& Jereki, L. (2019). Spatial variability in beach biogeomorphology in a tropical archipelago. Earth Surface Processes and Landforms, 44(9), 1860-1875.

https://doi.org/10.1002/esp.4604

Link to publication record in Ulster University Research Portal

Published in:

Earth Surface Processes and Landforms

Publication Status:

Published (in print/issue): 01/07/2019

DOI:

10.1002/esp.4604

\section{Document Version}

Author Accepted version

\section{General rights}

Copyright for the publications made accessible via Ulster University's Research Portal is retained by the author(s) and / or other copyright owners and it is a condition of accessing these publications that users recognise and abide by the legal requirements associated with these rights.

\section{Take down policy}

The Research Portal is Ulster University's institutional repository that provides access to Ulster's research outputs. Every effort has been made to ensure that content in the Research Portal does not infringe any person's rights, or applicable UK laws. If you discover content in the Research Portal that you believe breaches copyright or violates any law, please contact pure-support@ulster.ac.uk. 
1 Spatial variability in beach biogeomorphology in a tropical archipelago

2

3 Shannon Gore ${ }^{1}$, J. Andrew G. Cooper ${ }^{2}$, Derek W. T. Jackson², Lianna Jarecki

4

5 1. Coastal Management Consulting, P. O. Box 3252 PMB \#1103, Road Town, Tortola

6 VG1110, British Virgin Islands

7 2. Centre for Coastal and Marine Research, School of Environmental Sciences,

8 University of Ulster, Coleraine, Northern Ireland, BT52 1SA, United Kingdom.

9 3. Guana Science, 257 Park Ave. S. \#700, New York, NY 10010.

11 ABSTRACT

13 Beaches of tropical island coasts exhibit high levels of diversity in composition and form

14 in comparison with their continental counterparts. To investigate the nature and origin of

15 this diversity, individual beach morphology and sedimentology was investigated in the

16 British Virgin Islands (BVI), a Caribbean archipelago of $>60$ high volcanic and low reef

17 islands. The islands exhibit a diversity of orientations (some facing the Atlantic and

18 some the Caribbean), elevation and gradient, rock type and wave energy. An

19 examination of 100 beaches in the archipelago revealed a first order division into sand

20 (70 beaches) and coral rubble (30 beaches). These beaches occur in seven planform

21 types (determined by the antecedent geological framework) and are further subdivided

22 according to shoreface type (seagrass, sandy shoreface, or reef). Mainland-attached 
23 headland-embayment beaches are the most common form of sand beach while coral rubble beaches usually occur as barriers that enclose salt ponds and wetlands.

Among sand beaches, carbonate content is greatest on Atlantic-facing beaches, and coral rubble beaches are more common on Caribbean-facing beaches. Grain size characteristics on sandy beaches are highly variable and range from fine to very coarse sands while coral rubble beaches range up to boulder-sized clasts. The local source material is a primary determinant of sediment composition.

32 The local factors such as the underlying geology, source and availability of sediments 33 are the primary determinants of beach form, composition and texture in the BVI. 34 Oceanographic and climatic conditions such as the prevailing easterly trade winds and waves which seasonally range in direction from east-northeast to southeast as well as beach orientation to Atlantic or Caribbean facing waves also contribute to the variability,

37 but in a secondary role.

\section{INTRODUCTION}

40 The morphology of a beach reflects a variety of interacting variables including sediment 41 texture and composition, wave energy and geologic setting (Pilkey et al., 2011, Loureiro

42 et al., 2012). A number of studies have examined the interaction between sediment 43 texture and wave conditions (e.g. Wright and Short, 1984) to develop generic models of 44 beach morphology and beach behaviour. The geological influence on beach form 45 (geologic setting and sediment volume) has received comparatively less attention and 
46 yet is known to be an important determinant of beach form and behaviour (Jackson et 47 al., 2005; Jackson and Cooper, 2009; Short, 2010). On tropical beaches, the influences of biogeomorphology (via reefs and seagrass beds) and sediment texture (imparted by 49 a diversity of bioclastic shape and size) are likely to be particularly important influences 50 on beach form (Gallop et al., 2013).

52 With a few notable exceptions (e.g. Bush et al., 1995; Woodroffe, 2002; Wong, 2003;

53 Kench and Brander, 2006; Duvat, 2007) the geomorphology of beaches on small 54 tropical islands has received comparatively little attention. The British Virgin Islands (BVI) (Figure 1) contains a large number of beaches of variable form and texture within a relatively small area. Despite many beaches in the BVI having ecological, economic 57 and socio-cultural importance; they are severely threatened by development of 58 commercial and residential properties and beach management is in the early stages of 59 implementation (Gore, 2007).

60

61 In this paper, we seek to examine the nature and origin of beach form diversity in 62 tropical island settings and look at individual beach morphology and sedimentology 63 using the BVI as a case study. Specifically, we focus on spatial variability in beach form 64 throughout the region of over 60 islands. The objective is to provide a first-order 65 baseline classification of the beaches and to interpret their distribution and form in terms 66 of their oceanographic and geological setting.

67 68 
70 Field investigations of 70 sandy and 30 coral rubble beaches (See Figures 2-6 for

71 localities) were conducted between 2005 and 2009. Selection of beaches was based

72 primarily on ease of access by land or sea. Foreshore characteristics, terrestrial

73 environments adjacent to the beach and planforms were first identified from both the

74 BVI Coastal Resource Atlas (CRI) (Blair Meyers et al., 1992) and 2002 aerial photos $75 \quad(1: 2500)$.

76

77 Remotely sensed site characteristics were verified by field visits that also involved beach sediment sampling and snorkelling observations in the area immediately seaward 79 of the beach. The subtidal foreshore was characterised based on morphology between 80 the shoreline and $20 \mathrm{~m}$ depth, where the forereef is generally located. Three different 81 foreshore morphologies were identified (see Figures 10-13 for examples): headland82 attached linear reef; terrace flat (with or without reef or marine vegetation); and graded 83 reef (with or without reef or marine vegetation).

85 Surface sand samples were collected at 70 sandy beaches. At each beach samples $86(\sim 100 \mathrm{~g})$ were collected from the swash zone, mid-beachface and berm. All 210 87 samples were taken from the centre of the beach planform. A semi-automated settling 88 tube was used for sediment analysis (Johansen and Larsen, 1998). Carbonate 89 percentages were determined by weight-loss acid digestion (Molnia, 1974). A 90 multivariate statistical analysis of sandy beaches was carried out using K-means 91 clustering analysis (MacQueen, 1967) based on grain size, sediment composition and 
92 foreshore characteristics. Foreshore characteristics were assigned numerical values (1-

93 yes, 2-no) for direction to prevailing wind and wave regimes and a second numerical

94 value was assigned for each a fronting reef, sand or seagrass bed. All results were 95 mapped using ArcGIS 9.3.

96

97 Mean clast size at each of 30 coral rubble beaches was determined using Wolman's (1954) sampling technique for coarse bed surfaces. This method determines grain sizes based on relative area covered instead of relative weight. A $50 \mathrm{~m}$ transect measuring tape was laid shore-parallel mid-way up the beachface of each coral rubble beach. Clasts directly below the transect line at $1 \mathrm{~m}$ intervals were measured at their b-axis 102 with a total sample size of 50 clasts per beach.

\section{STUDY AREA}

105 The British Virgin Islands (BVI) comprise a small volcanic archipelago (Figure 1) 106 bounded by the Atlantic Ocean to the north and the Caribbean Sea to the south. The 107 BVI has a total land area of $151 \mathrm{~km}^{2}$ and human population of 35,015 (CIA, 2017). The 108 Territory consists of over 60 high volcanic islands. Anegada, the second largest island 109 in the Territory, however, is a reef platform with a maximum elevation of 8m (Martin110 Kaye, 1959; Atwater et al., 2012). The 6km-wide Sir Francis Drake channel (maximum 111 depth 50m) divides the BVI into two high island chains. Northeast of Tortola and 112 southwest of Anegada is a shallow carbonate bank (average depth 25m) (Figure 1). A 113 number of low-lying mangrove cays occur on coral reef/rubble flats along the southern 114 coast of Tortola and Beef Island. One previously vegetated sand cay (vegetation 
115 removed by a recent category 5 hurricane) exists as part of an incipient tombolo (Sandy

116 Spit) and an unvegetated sand cay is forming on a narrow reef flat off Necker Island.

118 The BVI has a total coastline length of $\sim 420 \mathrm{~km}$ consisting of beaches (of sand, gravel, 119 and boulder-sized clasts) of both terrigenous and carbonate sediment, interspersed with 120 red mangroves (Rhizophora mangle), steep rocky cliffs or man-made bulkheads and 121 riprap. The island shorelines vary in orientation, underlying geology, and have a 122 diversity of adjacent marine features (coral reefs, marine vegetation, and carbonate 123 platforms).

125 The area is microtidal $(0.29 \mathrm{~m}$ during neaps to $0.65 \mathrm{~m}$ during spring tides). The trade 126 winds blow from ENE during winter (Dec.-Feb.), E during spring (Mar.-May) and SE 127 during summer and fall (June-Nov.). Maximum wind speeds occur during winter with a 128 minimum during the fall (Figure 7).

130 The Atlantic offshore wave climate is dominated by a persistent north-easterly to south131 easterly wave regime with deep-water significant wave heights averaging $1.7 \mathrm{~m}$ with an 132 average period of 8 seconds (NOAA's WAVEWATCH III models between 1997-2010, 133 location $19 \mathrm{~N}$ and $65 \mathrm{~W}$ with a $1.0 \times 1.25$-degree grid resolution). Swells, from the north 134 to northwest are occasionally generated from storms in the North Atlantic Ocean 135 between December and May (Cooper et al., 2013). Additionally, the BVI lies within the 136 Atlantic hurricane belt. The hurricane season extends from June to November, with 
137 August and September being most active (Hubbard, 1989). High-energy waves 138 generated from these storms may approach the islands from any direction (Figure 7).

The Caribbean Sea wind and wave regime is characterised by its generally benign yet persistent mean conditions forced by the easterly trade winds. Mean wave height and

142 period are $1.34 \mathrm{~m}$ and $4.9 \mathrm{~s}$, respectively. The semi-enclosed Caribbean Sea is 143 sheltered from distant Atlantic swells and dominated by locally produced wind waves 144 (Stopa et al., 2013). Storms control extreme conditions with intensity and frequency 145 variations increasing across the basin from south to north (Calverley et al., 2001). While some hurricane activity is generated in the eastern Atlantic, hurricanes may also 147 originate within the Caribbean Sea.

Only a few of the studied beaches are directly exposed to swell waves and even then, 150 this is seasonal. They include Long Bay - Belmont, Larmer, Cooper, Rogues, Trunk, 151 Josiah's and Lambert Bays on Tortola; North Beach, Guana Island; North Bay, Great 152 Camanoe; Wedgeo Bay, Ginger; South Sound and Handsome Bay on Virgin Gorda. 153 Extreme waves such as those produced from hurricanes may affect a wider range of 154 beaches, at least temporarily, as hurricanes may pass the islands from any direction, 155 although usually on an east-west track. Two known hurricanes (Category 4 Hurricane 156 Lenny 90km south of the BVI in 1999 and Category 3 Hurricane Omar 60k south of 157 the BVI in 2008) have passed on an anomalous west-east direction. Hurricanes may 158 pass either to the north or south of the island chain. Since 1871, ten hurricanes have 159 made a direct landfall on the BVI with only one category 5 hurricane (NOAA, 2011; 
160 Cangialosi et al., 2018). In contrast, swells approaching from a north-westerly direction 161 may last for a few days and expose beaches on west or north-west coasts.

\section{BEACH MORPHOLOGY \& PLANFORM}

164 The 100 beaches in this study were categorized according to both planform and 165 nearshore (profile) characteristics since beach planform provides insight into a range of 166 characteristics such as wave exposure, water transport pathways, formation of littoral 167 cells, temporal morphologic changes and sedimentary characteristics (Bowman et al., 168 2009). In this study, beach planforms in the BVI were divided into three categories:

169 mainland-attached beaches (64 examples), barriers (33 examples) and spits (3).

170 Mainland-attached and barrier categories were further sub-divided into linear, embayed 171 or cuspate forms (Figure 8 and Table 1).

173 Mainland-attached beaches are by far the most common type of beach in the BVI with 174 sediment having been driven onshore over steeply dipping bedrock into small coastal 175 re-entrants. These beaches are often dissected by freshwater drainage pathways locally 176 called 'ghuts' that drain directly into the sea and provide a source of terrigenous 177 sediments from pebble to boulder size terrigenous rock.

179 Linear beaches are relatively straight and continuous beaches of sand or coral rubble. 180 They are best developed on Anegada where the beach forms a continuous rim around 181 the island (approximately $48 \mathrm{~km}$ ) as either mainland-attached or barrier beaches. Since 182 the high islands have irregular coastlines, linear beaches are not common. However, a 
183 few mainland-attached linear beaches exist on smaller volcanic islands with lower relief, 184 such as Pelican Island, and along the southern coast of Tortola.

186 Embayed beaches consist of discrete sedimentary units bounded by headlands. They 187 vary in morphology according to headland spacing and orientation, bay indentation, 188 length and sediment characteristics (Klein and Menezes, 2001), but typically assume a 189 concave planform controlled by wave refraction and diffraction around adjacent 190 headlands. Beaches in these embayments tend to be swash-aligned (Woodroffe, 191 2002). Embayed beaches bounded by bedrock outcrops are the most common form in 192 the BVI.

194 Cuspate beaches are formed from converging or drift aligned waves influenced by 195 nearshore bathymetry. Barrier cuspate beaches in the BVI exist as small cuspate 196 forelands. These develop as a sequence of ridges formed at a high angle to the overall 197 beach orientation (McNinch and Luettich, 2000). They often enclose lagoons and 198 marshes (Woodroffe, 2002). A series of well-developed cuspate forelands are located 199 on the south-western coast of Anegada at Pomato Point as well as on the northern side 200 of Dead Chest (Figure 8).

201

202 Barrier beaches are widely developed around the BVI coast. On the volcanic islands 203 they enclose salt ponds or wetlands and are associated with areas of lower gradient 204 bedrock. The barriers are typically composed of coral rubble that occasionally has a 205 veneer of sand. Barrier beaches form as a result of a linear reef developing across the 
206 entrance of a bay. With the rapid growth rates of corals such as Acroporids (Lidtz and

207 Shinn, 1991; Jarecki, 2004), the reef crest may become exposed over time (Cox et al., 208 2000). Red mangroves (Rhizopora mangle) then colonize the reef crest to form a 209 complex network of roots that trap mangrove peat and sediments (Ellison and 210 Farnsworth, 1996). Sediments that have accumulated on these barrier frameworks 211 range in size from medium sand to boulder-sized coral clasts. Back-barrier lagoons are 212 important influences on beach behaviour in that they capture fine sediment from 213 inflowing streams (MacDonald et al., 1997) and provide space for potential landward 214 retreat of barriers.

216 Mainland-attached cuspate beaches in the BVI occur as tombolos that connect two solid 217 outcrops. Tombolos form when the distance between the two outcrops is equal to or 218 less than 1.5 times the width of the offshore structure (Sunamura and Mizuno, 1987). In 219 the BVI, they form between islands, rock outcrops or reefs. Sandy Spit is an incipient 220 tombolo (Figure 9) developing between Green Cay and some shallowly submerged 221 beachrock outcrops. Three spits were identified, two composed of coralline boulders 222 (The Bluff at South Sound, Salt Island and South Sound Spit, Virgin Gorda) and one 223 composed of sand (Sprat Point, Beef Island).

224

225 FORESHORE/SHOREFACE MORPHOLOGY

226 Most temperate beaches have a sandy shoreface. In the tropics, however, shoreface 227 development is often inhibited by the presence of biogenic structures (Short, 2006). 228 Some BVI beaches are fronted by sandy shorefaces while others are fronted by coral 
229 reefs or seagrass meadows. The absence of a mobile shoreface influences the 230 potential for morphological change to the beachface and backbeach in response to

231 changing wave conditions. A classification of BVI beaches based on 232 shoreface/nearshore morphology (Figure 7) identifies an initial split between beaches 233 with sandy shorefaces and those without. Those that lack a shoreface further divide 234 into those fronted by one of three types of fringing reef or those fronted by seagrass 235 beds.

\section{Coral reef foreshores}

238 The majority of reefs around the high volcanic islands of the BVI are fringing reefs that 239 have developed close to shore on a narrow shelf between the low tide shoreline and the $24020 \mathrm{~m}$ bathymetric contour. Anegada's Horseshoe Reef covers approximately $133 \mathrm{~km}^{2}$ 241 and is composed of two distinctive facies, a high-energy reef front on the north-north242 eastern windward side of the island, and a series of systematically distributed patch 243 reefs along the island's southern leeward side (Brown and Dunne, 1980). The fringing 244 reef on the north side of Anegada extends beyond the eastern end of the island to the 245 southeast for $\sim 14 \mathrm{~km}$. This entire reef system is the largest contiguous reef in the BVI 246 and is a major source of the carbonate sediments found on the Anegada Bank between 247 Anegada and Tortola. Many of the fringing reefs in the high volcanic islands of the BVI 248 lack an identifiable reef crest.

250 Fringing reefs fronting beaches are common throughout the BVI and our study shows 251 that there is further variability in form of fringing reefs backed by beaches. Three types 
252 of fronting reef exist in conjunction with BVI beaches: headland-attached reefs, terrace

253 flats and graded reefs.

254

255 Headland-attached linear reefs are $<500 \mathrm{~m}$ offshore and usually extend across an 256 embayment (Figure 11). Such reefs have a distinct reef crest, originally composed of 257 Acropora palmata but since the outbreak of white-band disease in the late 1970s 258 (Aronson and Precht, 2001), Orbicella annularis has become the dominant reef species 259 in the BVI. The reef crest may be partially exposed on extremely low tides and depth in 260 the lagoon can exceed $5 \mathrm{~m}$. These reefs intercept much of the incoming wave energy 261 but secondary waves and wind waves form in the fetch-limited back-reef area.

263 A terrace flat is a backreef environment or reef flat, although it does not always have a 264 fronting reef but instead a broad shallow seagrass or carbonate bank. A terrace flat is a 265 low-gradient, broad and shallow lagoon, composed of unconsolidated sediments, 266 seagrasses, small patch reefs and/or most often coral rubble (Figure 12). The irregular 267 seafloor topography exerts a strong control on contemporary wave behaviour. Strong 268 energy dissipation occurs over the initial fore reef, substantially reducing the total 269 energy contained in the wave forms. Subsequent wave energy reduction occurs through 270 shoaling processes over the shallow $(<1-5 \mathrm{~m})$ waters of the reef flats. Short (2006) 271 noted several such beaches in tropical Australia where the reef flat extended to the 272 shore. 
274 Graded reefs differ from reef flats in that the cross-shore profile is steeper so less

275 energy is dissipated through breaking and shoaling (Figure 13). Coral relief and

276 coverage is commonly higher than on reef flats but there is no distinctive reef crest. The

277 reef may cover the entire seabed or be dissected by sand-filled channels (spur and 278 groove formations).

279

280

\section{Seagrass meadow foreshores}

281 The presence of seagrass on the foreshore plays an important morphological function 282 on adjacent beaches. Seagrass beds attenuate wave energy (Fonesca and Cahalan, 283 1992; Koch, 1996; Verduin and Backhaus, 2000), stabilize bottom sediments (Fonseca, 284 1989), and interact with hydrodynamics restricting morphological response during 285 storms to the beachface and berm (Basterretxea et al., 2004; Vacchi et al., 2017). An 286 additional influence on beach morphology occurs through the accumulation of leaf litter 287 forming banquettes which may enhance dune formation on the backshore (Hemminga 288 and Nieuwenhuize, 1990; Kirkman and Kendrick, 1997) or foreshore, depending on the 289 exposure to dominant waves (Simeone and Falco, 2012). Extensive seagrass meadows 290 occur throughout the BVI, with several bays exhibiting high densities of Thalassia 291 testudinum, Syringodium filiforme, Halodule wrightii and/or more recently the invasive 292 species, Halophila stipulacea. A distinctive beach step is usually developed at the 293 junction of seagrass bed and beachface. 
296 Several sandy beaches on the north east coast of Tortola lack offshore reefs and are 297 exposed to high Atlantic wave energy. These are the only beaches to have a mobile 298 sandy shoreface. Observations during large swell events (Cooper et al., 2013) show 299 that these beaches suffer backshore erosion, reduction in gradient and development of 300 nearshore bars during high wave energy. Post-storm recovery involves the transfer of 301 sediment from nearshore bars to the beachface, as in unconstrained temperate 302 beaches (Wright and Short, 1984).

\section{BEACH COMPOSITION}

305 From a textural perspective, beaches in the BVI may be broadly divided into sand and 306 coral rubble. There is, however, additional variability in carbonate content and sediment 307 texture. These variations and the distribution of such beaches around the archipelago 308 are described below.

\section{Coral rubble beaches}

311 Numerous beaches throughout the BVI are composed of coral rubble ranging in size

312 from fine to coarse gravel $(4 \mathrm{~mm}$ to $>64 \mathrm{~mm}$ ). In many cases, this is augmented by 313 coarse terrigenous clasts from adjacent headlands and cliffs, and a few beaches have a 314 partial and temporary cover of sand. Clasts range from smooth well-rounded corals no 315 longer identifiable as a particular coral species to angular, identifiable pieces of coral 316 that have simply been broken from the reef and thrown onto the beach. Twelve of the 31730 coral rubble beaches in this study were backed by multiple coral rubble ridges. 
319 In the BVI, coralline rubble beaches occur in all seven of the planforms described

320 above. Figure 8 displays a mainland-attached linear beach (Oil Nut Bay, Virgin Gorda),

321 embayed barrier (South Sound, Salt Island) and cuspate forelands (Dead Chest). Figure

32214 shows the remaining three planforms not previously shown.

324 The largest mean clast sizes were recorded at the Bluff at South Sound, Virgin Gorda $325(280 \mathrm{~mm})$ and South Sound, Salt Island $(247 \mathrm{~mm})$, both of which are spits. The longest 326 coral rubble beach $(1.8 \mathrm{~km})$ is at Banana Wharf, Beef Island (Figure 14) and the widest 327 is $80 \mathrm{~m}$ at the Bluff South Sound, Salt Island).

\section{Sand beaches}

330 Sand beaches on the high islands in the BVI occur in embayments along the Atlantic331 facing (northern) side of both the north and southern island chains. Few sandy beaches 332 occur on the southern (Caribbean facing) side of the islands. Except for beaches on the 333 northeast shore of Tortola (where they reach $50-80 \mathrm{~m}$ wide) sand beaches are generally 334 less than $30 \mathrm{~m}$ wide.

336 Carbonate content of the 70 sandy beaches varied from 10\%-99\% (Table 1). In general, 337 the highest carbonate content was on Atlantic-facing beaches, with the majority being 338 on Anegada and the northern chain of islands. Beaches with the lowest carbonate 339 content were generally located on the southern island chain. There, deeply weathered 340 bedrock made a significant contribution of terrigenous material to the beach sand 341 volume. 
343 Sand beach mean grain size ranged from fine to very coarse. The finest grain sizes

$344(0.19 \mathrm{~mm}-0.23 \mathrm{~mm})$ in the swash zone were found on north shore beaches on Tortola.

345 Very coarse sand $(1.02 \mathrm{~mm}$ to $1.30 \mathrm{~mm})$ in the swash zone was primarily found on the 346 southern island chain. The mid beachface sediments ranged from fine to very coarse 347 sands but medium sand was most common. Berm grain sizes ranged from fine to 348 coarse sand. The northern Tortola beaches had fine-grained sands on the berm.

350 Multivariate analysis (using SPSS 19.0 statistical software) was used to identify 351 potential groupings of beaches based on carbonate content, grain size, and foreshore 352 geomorphology (fringing reefs; seagrasses and sandy shorefaces. Using the data 353 collected, a K-means clustering with Minikowski as a distance measure $(n=3)$ revealed 354 three stable clusters with centroids that classified the data set with $85.4 \%$ of variance 355 being explained within the clusters (SSB/(SSW+SSB)). The external consistency 356 between the clusters was strong with $\mathrm{t}(\mathrm{c} 1-\mathrm{c} 2)=8.71$; $\mathrm{t}(\mathrm{c} 1-\mathrm{c} 3)=5.64$ and $\mathrm{t}(\mathrm{c} 2-\mathrm{c} 3)=$ 3572.89 and $p<0.01$ for all tests, indicating solid separations between clusters. For all three 358 clusters, the foreshore geomorphology variable did not indicate significance. The 359 distribution of beaches in each cluster is shown in Figure 15.

361 The first cluster identified two beaches that had coarse sand in the swash zone $362(0.905 \mathrm{~mm}$ mean grain size, $\mathrm{p}<0.05)$; fine sand on the berm $(0.276$ mean grain size, $363 \mathrm{p}<0.05)$ and significantly less carbonate content than the other clusters $(20.2 \%$ 364 carbonate, $\mathrm{p}<0.05)$. These two beaches, Salt Bay, Salt Island and South Sound, Virgin 
365 Gorda, both in the southern high island chain, have different orientations, Atlantic- and 366 Caribbean-facing respectively, but both are flanked by deeply weathered bedrock which 367 makes a significant contribution to the beach sediment supply.

368

369 The second cluster had 52-member beaches and accounted for $74.3 \%$ of the 370 observations. Distinctive features of this group of beaches were fine sand in the swash 371 zone $(0.527 \mathrm{~mm}, \mathrm{p}<0.05)$ and high carbonate content $(89.355 \%, \mathrm{p}<0.05)$. The majority 372 of these beaches are located along Atlantic-facing shores on the northern island chain. 373 Some have fringing reefs and others have mobile sandy shorefaces.

375 The third cluster had 16 members (22.9\% of the beaches). These beaches had coarser 376 grain sizes in the mid-beachface $(0.483 \mathrm{~mm}, p<0.05)$ and berm $(0.423 \mathrm{~mm}, p<0.05)$. The 377 mean percentage of carbonate fell between the other two clusters $(58.47 \%, p<0.05)$. 378 The majority of these beaches (except for Trellis Bay and Sprat Point on Beef Island) 379 are located in the southern high island chain. 380

381 Foreshore geomorphology did not appear to influence carbonate composition. The north 382 shore of Tortola has three types of fringing reefs, and some beaches lack a reef but 383 there was no correlation between the percentage of carbonate found on beaches and 384 the nearshore topography. Neither did foreshore geomorphology influence grain size. 385 386 DISCUSSION 
387 Beach morphology in the BVI is exceedingly variable and reflects the combined 388 influence of dynamic and geological factors. The entire region is microtidal and wave 389 action is thus concentrated in a narrow band, except during hurricanes when surges 390 elevate the water level and shift the focus of wave energy. Modally energetic waves 391 occur on the Atlantic-facing shores, while the Caribbean-facing shores are 392 characterised by low wave energy. All, shorelines, however, are affected by episodic 393 hurricanes. Modally high wave energy on the Atlantic shorelines coincides with the 394 distribution of carbonate-rich sandy beaches and points to a causative relationship. We 395 suggest that on these shorelines, the breakdown of carbonate material into finer size 396 grades is accomplished under modal wave conditions. Consequently, hurricanes deliver 397 the pre-abraded sand fraction to the shoreline.

399 In contrast, hurricanes on the sheltered Caribbean shorelines, impact on reefs that have 400 not been subject to the same degree of abrasion under modal conditions and thus large 401 clasts are broken off and delivered to the high tide shoreline to create the coral rubble 402 beaches and ridge complexes. Geister $(1977,1980)$ noted that more sheltered 403 Caribbean reefs have a higher degree of Acropora palmata development on the reef 404 crest, which is consistent with the high proportion of this species in rubble beaches. 405 Coral rubble may derive either from corals broken in situ in depths up to $12 \mathrm{~m}$ 406 (Hernandez-Avila et al., 1977) or from offshore zones in which coral rubble previously 407 accumulated. Characteristics of foreshore slope and morphology, shelf width, and water 408 depth determine whether or not coral rubble is transported onshore or offshore, 409 (Hughes, 1999). Descriptions of coral rubble beaches elsewhere in the Caribbean and 
410 Pacific (Scoffin, 1993; Bries et al., 2004; Morton et al., 2008, Scheffers et al., 2009)

411 focus on coarse clastic deposition during storm or tsunami events in which coralline

412 rubble is transported onshore to create ridges, and over time, ridge complexes.

414 The lower proportion of carbonate in sandy beaches on the southern island chain is also

415 consistent with the lower rates of sand production in modally lower energy conditions.

416 Consequently, there is dilution of carbonate by terrigenous sediment input from steep

417 weathered slopes.

419 The underlying geologic framework determines the physical boundaries within which a 420 beach forms and evolves (Jackson and Cooper, 2009) while physical wave processes, 421 currents and sediment transport, shape the beach within these constraints. In tropical 422 settings, the underlying geological framework is particularly important in constraining the 423 beach and influencing the sediment source, as well as modifying wave dynamics

424 (particularly through the presence/absence of reefs or simply through the degree of 425 shelter offered by beach orientation). All beaches exhibit some degree of geological 426 control on beach planform. Most are located between distinct headlands which set 427 longshore limits to beach extent. Both sand and rubble beaches occur in seven 428 planform types all of which are dictated by the antecedent coastal morphology and the 429 availability of sediment. The same range of planform types was noted on neighbouring 430 Puerto Rico (Bush et al., 1995). Only on Anegada are extensive, linear beaches 431 prevalent. 
433 The beaches are nearly all constrained in the vertical dimension by some form of 434 fronting biogenic structure (reef or seagrass bed) that precludes development of a 435 mobile shoreface and limits beach development to the beachface, berm and backbeach. 436 Fringing reefs fronting beaches are common in Australia where they were identified as a 437 distinctive beach type (Short, 2006). Incoming wave energy is significantly attenuated 438 by coral reefs (e.g. Roberts, 1975; Young, 1989) and this exerts an important influence 439 on beach form (Short, 2006). This also limits the spatial mobility of such beaches during 440 wave events compared to those with shorefaces (De Alegria-Arzaburu et al., 2012).

\section{Conclusions}

444 Beach morphology $(n>100)$ in the BVI archipelago is characterised by seven planforms 445 and several profile categories based on a sandy shoreface, fronting seagrass bed or 446 one of three reef profiles. These are the result of antecedent geology and 447 biogeomorphology, which sets horizontal (planform) and vertical (profile) constraints on 448 accommodation space available for beach development and controls the limits of 449 mobility of unconsolidated beach sediment.

451 Beaches are composed of sand or coral rubble. Coral rubble beaches dominate the

452 modally low energy Caribbean-facing shorelines while sand dominates those facing the 453 high-energy Atlantic-facing shores. This paradoxical primary textural division (sand and 454 rubble associated with modally high and low energy, respectively) is explained by the 455 varying reef morphology and the ability of hurricanes to break large clasts from modally 
456 low energy environments whose energy-attenuating ability is minimal. Modally high-

457 energy reefs in contrast have greater wave energy dissipation.

458

459 Sand beaches vary in carbonate content, with significant terrigenous components on 460 several volcanic islands with adjacent deeply weathered and steep slopes. Carbonate 461 content is almost $100 \%$ on most Atlantic-facing beaches, irrespective of whether they 462 have a fronting reef.

463

464 Three main textural and compositional groups of sand beach are identified by cluster 465 analysis. These have a clear spatial distribution with high carbonate content beaches on 466 Atlantic-facing beaches; intermediate carbonate levels on islands in the southern Island 467 chain; and very low carbonate beaches in locations adjacent to deeply weathered 468 bedrock sources. The pattern of distribution of grain sizes across the beach was 469 broadly consistent within each of these categories and differed between them.

470

471 Geological inheritance and sediment source are important determinants of beach form, 472 composition and texture in this tropical archipelago. Dynamic influences (wave height 473 and direction, and storm occurrence) also contribute the variability, but in a secondary 474 role.

475

\section{REFERENCES}

477 Aronson, R.B. and Precht, W.F., 2001. White-band disease and the changing face of 478 Caribbean coral reefs. Hydrobiologia, 460, 25-38. DOI: 10.1023/A:1013103928980 
Atwater, B. F., ten Brink, U. S., Buckley, M., Halley, R. B., Jaffe, B. E., López-Venegas,

A. M., Reinhardt, E. G., Tuttle, M. P., Watt, S., and Wei, Y. 2012. Geomorphic and 482 stratigraphic evidence for an unusual tsunami or storm a few centuries ago at Anegada, 483 British Virgin Islands. Nat. Hazards, 63, 51-84. DOI: 10.1007/s11069-010-9622-6

485 Basterretxea, G. Orfila, A. Jordi, A. Casas, B. Lynett, P. Liu, P. L. F. Duarte, C. M. and

486 Tintoré, J., 2004. Seasonal Dynamics of a Microtidal Pocket Beach with Posidonia 487 oceanica Seabeds (Mallorca, Spain). Journal of Coastal Research, 20, 1155 - 1164.

488 DOI: $10.2112 / 03-0027 R$

489

490 Blair Myers, C.N., Sheppard, C.R. C. and Bythell, J.C., 1992. A Coastal Resource Atlas 491 of the British Virgin Islands. Chatham, United Kingdom: Natural Resources Institute. 4pp 492 and 22 maps.

493

494 Brown, B.E. and Dunne, R.P., 1980. Environmental Controls of Patch-reef Growth and 495 Development. Marine Biology, 56, 85-96. DOI: 10.1007/BF00390598

497 Bowman, D., Guillén, J., López, L. and Pellegrino, V., 2009. Planview Geometry and 498 Morphological Characteristics of Pocket Beaches on the Catalan Coast (Spain), 499 Geomorphology, 108,191-199. DOI: 10.1016/j.geomorph.2009.01.005 
501 Bries, J.M., Debrot, A.O. and Meyer, D.L., 2004. Damage to the leeward reefs of 502 Curacao and Bonaire, Netherlands Antilles from a rare storm event: Hurricane Lenny, 503 November 1999. Coral Reefs, 23, 297-307. DOI: 10.1007/s00338-004-0379-9

504

505 Bush, D.M., Webb, R.M.T., Liboy, J.G., Hyman, L. and Neal, W.J. 1995. Living with the 506 Puerto Rico Shore. Duke University Press, Durham, North Carolina, 193pp.

507

508 Calverley, M. J., D. Szabo, V. J. Cardone, E. A. Orelup, and M. J. Parsons, 2002: Wave 509 climate study of the Caribbean Sea. Proc. Seventh Int. Workshop on Wave Hindcasting 510 and Forecasting, Banff, AB, Canada, Environment Canada. [Available online at 511 http://www.waveworkshop.org/7thWaves/Papers/Calverly etal.pdf.]

512

513 Cangialosi, J.P., Lato AS, Berg R. 2018. Tropical Cyclone Report - Hurricane Irma. 514 National Hurricane Center, 2018. 111pp.

515

516 Central Intelligence Agency (CIA), 2017. The CIA World Fact Book. Available at: 517 https://www.cia.gov/library/publications/the-world-factbook/geos/vi.html (Accessed 24 518 Feb. 2018)

519

520 Cooper, J.A.G. Jackson, D.W.T. and Gore, S. 2013. A groundswell event on the coast 521 of the British Virgin Islands: variability in morphological impact. Journal of Coastal 522 Research, Special Issue 65, 696-701. DOI: 10.2112/SI65-118.1 
524 Cox, R., Atkinson, R. K., Bear, B. R., Brandriss M. E., Chokel, C. B., Comstock, J. C., 525 Gutmann, E.D., Interess, L.B., Schildgen, T.F., Teplitzky S.J. and Willis, M.P., 2000.

526 Changes in a fringing reef complex over a thirty-year period: Coral loss and lagoon

527 infilling at Mary Creek, St. John, U. S. Virgin Islands. Bulletin of Marine Science, 66, $528 \quad 269-277$.

529

530 De Alegria-Arzaburu, A. R., Mariño-Tapia, I., Enriquez, C., Silva-Casarín, R., \& 531 González-Leija, M. (2012). Morphodynamics of a Caribbean beach fringed by a coral 532 reef. Coastal Engineering Proceedings, 1(33), sediment-119. DOI: 533 10.9753/icce.v33.sediment.119 534

535 Duvat, V., 2007. Proposition de typologie des plages coralliennes (océan Indien 536 occidental). Zeitschrift für Geomorphologie, 51, 307-325. DOI: 10.1127/0372$5378854 / 2007 / 0051-0307$

539 Ellison, A.M. and Farnsworth, E.J., 1996. Spatial and temporal variability in growth of 540 Rhizophora mangle saplings on coral cays: links with variation in insolation, herbivory, 541 and local sedimentation rate. Journal of Ecology, 84, 717-731. DOI: 10.2307/2261334

542

543 Fonseca, M. S., 1989. Sediment stabilization by Halophila decipiens in comparison to 544 other seagrasses. Estuarine, Coastal and Shelf Science, 29, 501-507. DOI: $545 \quad 10.1016 / 0272-7714(89) 90083-8$ 
547 Fonesca, M.S. and Cahalan, J.A., 1992. A preliminary evaluation of wave attenuation by 548 four species of seagrass. Estuarine, Coastal and Shelf Science, 35, 565-576. DOI:

$549 \quad 10.1016 / \mathrm{S} 0272-7714(05) 80039-3$

550

551 Gallop S. L., Bosserelle C., Eliot I., Pattiaratchi C.B., 2013. The influence of coastal 552 reefs on spatial variability in seasonal sand fluxes. Marine Geology, 344, 132-143. 553 doi:10.1016/j.margeo.2013.07.016.

554

555

556 Geister, J., 1977. The influence of wave exposure on the ecological zonation of 557 Caribbean coral reefs. Proceedings of Third International Coral Reef Symposium Vol. 2: 558 Geology. Miami, Florida: Rosenstiel School of Marine and Atmospheric, 1, 23-29.

559

560 Geister, J., 1980. Calm-water reefs and Rough Water Reefs of the Caribbean 561 Pleistocene. Acta Palaeontologica Polonica, 25, 541-561.

562

563 Gore, S., 2007. Framework development for beach management in the British Virgin 564 Islands. Ocean \& Coastal Management, 50, 732-753. DOI: 565 10.1016/j.ocecoaman.2007.03.004

566

567 Hernandez-Avila, M.L., Roberts, H.H., Rouse, L.J., 1977. Hurricane generated waves 568 and coastal boulder rampart formation. Proceedings of the 3rd International Coral Reef 569 Symposium, Miami2, 72-78. 
571 Hemminga, M.A. and Nieuwenhuize, J., 1990. Seagrass wrack induced dune formation

572 on a tropical coast (Banc d'Arguin, Mauritania). Estuarine Coastal and Shelf Science,

573 31, 499-502. DOI: 10.1016/0272-7714(90)90040-X

574

575 Hughes, T.P., 1999. Off-reef transport of coral fragments at Lizard Island, Australia.

576 Marine Geology, 157, 57-72. DOI: 10.1016/S0025-3227(98)00187-X

577

578 Hubbard, D.K., 1989. Modern Carbonate environments of St. Croix and the Caribbean:

579 A general overview. In: Hubbard, D.K., (Ed). Terrestrial and Marine Geology of St.

580 Croix, US Virgin Islands. West Indies Laboratory Special Publication, 9, 85-94.

581

582 Jackson, D.W.T., Cooper, J.A.G., and del Rio, L., 2005. Geological control of beach

583 morphodynamic state. Marine Geology, 216, 297-314. DOI:

$584 \quad$ 10.1016/j.margeo.2005.02.021

585

586 Jackson, D.W.T. and Cooper, J.A.G., 2009. Geologic Control on Beach Form:

587 Accommodation Space and Contemporary Dynamics. Journal of Coastal Research, SI $58856,69-72$.

589

590 Jarecki, L., 2004. Salt Ponds of the British Virgin Islands: Investigations in an 591 unexplored ecosystem. Canterbury, United Kingdom: University of Kent. Unpublished 592 PhD thesis. 183 pp. 
594 Johansen, C., Larsen, T. 1998. Measurement of settling velocity of fine sediment using

595 a recirculated settling column. Journal of Coastal Research, 14, 132-139.

596

597 Kench, P.S. and Brander R.W., 2006. Response of reef island shorelines to seasonal

598 climate oscillations: South Maalhosmadulu Atoll, Maldives. J. Geophys. Res. 111, 599 F01001, doi: 10.1029/2005JF000323.

600

601 Kirkman, H. and Kendrick, G.A., 1997. Ecological Significance and Commercial 602 Harvesting of Drifting Beach-Cast Macro-Algae and Seagrasses in Australia: A review. 603 Journal of Applied Phycology, 9 (4). P 311-26. DOI: 10.1023/A:100796550

604

605 Klein, A.H.F. and Menezes, J.T. 2001. Beach Morphodynamics and Profile Sequence 606 for a Headland Bay Coast. Journal of Coastal Research, 17, 814-835.

607

608 Koch, E.W., 1996. Hydrodynamics of a shallow Thalassia testudinum bed in Florida, 609 USA. In: Kuo, J., Phillips, R.C., Walker, D.I., Kirkman, H., (Eds). Seagrass Biology: 610 Proceedings International Workshop, Rottnest Island, Western Australia, 25-29 January 611 1996. Crawley, Australia: Faculty of Sciences, University of Western Australia, 105-110.

613 Lidz, B. and Shinn E.A., 1991. Paleoshorelines, reefs, and a rising sea: South Florida, 614 U.S.A. Journal of Coastal Research, 7, 203-229. 
616 Loureiro C., Ferreira O., Cooper J.A.G., 2012. Geologically constrained morphological 617 variability and boundary effects on embayed beaches. Marine Geology, 329-331, 1-15.

618 DOI: 10.1016/j.margeo.2012.09.010

619

620 MacDonald, L.H., Anderson, D.M. and Dietrich, W.E., 1997. Paradise threatened: Land 621 use and erosion on St. John US Virgin Islands. Environmental Management, 21, 851-

622 863. DOI: $10.1007 / \mathrm{s} 002679900072$

623

624 MacQueen, J., 1967. Some methods for classification and analysis of multivariate 625 observations. In: LaCam, L.M., Neyman, J., (Eds). Proceedings of the Fifth Berkeley 626 Symposium on Mathematical Statistics and Probability. Berkeley, California: University 627 of California Press, 281-297.

628

629 Martin-Kaye, P. H. A., 1959. Reports on the geology of the Leeward and British Virgin 630 Islands. Castries, St. Lucia: Voice Publishing. 117pp.

631

632 McNinch, J.E., Richard, A. and Luettich, Jr., 2000. Physical processes around a cuspate 633 foreland: implications to the evolution and long-term maintenance of a cape-associated 634 shoal. Continental Shelf Research, 20, 2367-2389. DOI: 10.1016/S0278$635 \quad 4343(00) 00061-3$

636 
637 Molnia, B.F., 1974. A Rapid and Accurate Method for the Analysis of Calcium 638 Carbonate in Small Samples. Journal of Sedimentary Petrology, 44, 589-590. DOI:

640

641 Morton, R.A., Richmond, B.M., Jaffe, B.E. and Gelfenbaum, G. 2008. Coarse-clast ridge 642 complexes of the Caribbean: a preliminary basis for distinguishing tsunami and storm643 wave origins. Journal of Sedimentary Research, 78, 624-637. DOI: $644 \quad 10.2110 /$ jsr.2008.068

645

646 NOAA (National Oceanographic and Atmospheric Administration) 2011. National 647 Hurricane Center Data Archive, "Best-track" database (HURDAT). Available at: 648 http://www.nhc.noaa.gov/pastall.shtml. (Accessed 12 June 2011).

649

650 Pilkey, O.H., Neal, W.J., Kelley, J.T., \& Cooper, J.A.G. 2011. The World's Beaches. 651 Berkeley, California: University of California Press, 283p.

652

653 Roberts, H.H., 1975. Physical processes in a fringing reef system. Journal of Marine 654 Research, 33, 233-260.

655

656 Scheffers, S.R., Haviser, J., Browne, T. and Scheffers, A., 2009. Tsunamis, hurricanes, 657 the demise of coral reefs and shifts in prehistoric human populations in the Caribbean. 658 Quaternary International, 195, 69-87. DOI: 10.1016/j.quaint.2008.07.016 659 
660 Scoffin, T.P., 1993. The geological effects of hurricanes on coral reefs and the 661 interpretation of storm deposits. Coral Reefs 12, 203-221. DOI: 10.1007/BF00334480

662

663 Short, A.D., 2006. Australian Beach systems- nature and distribution. Journal of 664 Coastal Research, 22, 11-27.

665

666 Short, A.D., 2010. Role of geological inheritance in Australian beach morphodynamics.

667 Coastal Engineering, 57, 92-97. DOI: 10.1016/j.coastaleng.2009.09.005

668

669 Simeone, S., De Falco, G., 2012. Morphology and composition of beach-cast Posidonia

670 oceanica litter on beaches with different exposures. Geomorphology 151-152,

671 224-233. DIO: 10.1016/j.geomorph.2012.02.005

672

673 Stopa, J. E., K. F. Cheung, H. L. Tolman, and A. Chawla, 2013: Patterns and cycles in

674 the Climate Forecast System reanalysis wind and wave data. Ocean Modell., 70, 207-

675 220, DOI:10.1016/ j.ocemod.2012.10.005.

676

677 Sunamura, T. and Mizuno, O., 1987. A study on the depositional shoreline forms behind 678 an island. Annual Report of the Institute of Geoscience, University of Tsukuba, 13, 71 67973.

680

681 Vacchi, M., De Falco, G., Simeone, S., Montefalcone, M., Morri, C., Ferrari, C., \& 682 Bianchi, C. N. (2017). Biogeomorphology of the Mediterranean Posidonia oceanica 
683 seagrass meadows. Earth Surface Processes and Landforms, 42(1), 42-54. DOI:

$684 \quad 10.1002 /$ esp.3932

685

686 Verduin, J.J. and Backhaus, J.O., 2000. Dynamics of plant-flow interactions for the 687 seagrass Amhibolis antarctica: Field Observations and Model Simulations. Estuarine 688 Coastal and Shelf Science, 50,185-204. DOI: 10.1006/ecss.1999.0567

689

690 Wright, L.D. and Short, A.D., 1984. Morphodynamic variability of surf zones and 691 beaches: a synthesis. Marine Geology, 56, 93-118. DOI: 10.1016/0025-3227(84)900086922

693

694 Wolman, M.G. 1954. Method of sampling coarse river bed material. Transactions, 695 American Geophysical Union, 35, 951-956. DOI: 10.1029/TR035i006p00951 696

697 Wong, P.P., 2003. Where have all the beaches gone? Singapore Journal of Tropical 698 Geography, 24, 111-132. DOI: 10.1111/1467-9493.00146

699

700 Woodroffe, C.D., 2002. Coasts: form, process and evolution. Cambridge: Cambridge 701 University Press. 623 pp.

702

703 Young, I.R., 1989. Wave transformation over coral reefs. Journal of Geophysical 704 Research, 94, 9779- 9789. DOI: 10.1029/JC094iC07p09779 705 
Figure Captions

707 Figure 1. Map of the larger islands in the British Virgin Islands and the country's location 708 within the greater Caribbean region.

709

710 Figure 2. Beach names and locations in the NW section of the BVI. Map indicates 711 sandy beaches with dots and coral rubble beaches with asterisks. Coral rubble beaches

712 listed are also italicized.

713

714 Figure 3. Beach names and locations in the north central section of the BVI. Map 715 indicates sandy beaches with dots and coral rubble beaches with asterisks. Coral rubble 716 beaches listed are also italicized.

717

718 Figure 4. Beach names and locations in the SW section of the BVI. Map indicates 719 sandy beaches with dots and coral rubble beaches with asterisks. Coral rubble beaches 720 listed are also italicized.

721

722 Figure 5. Beach names and locations in the SE section of the BVI. Map indicates sandy 723 beaches with dots and coral rubble beaches with asterisks. Coral rubble beaches listed 724 are also italicized.

725

726 Figure 6. Beach names and locations in the NE (Anegada) section of the BVI. Dots 727 mark location of sandy beaches. 
729 Figure 7. Wind and wave conditions around the BVI. Upper panel shows wind and

730

731

732

733

734

735

736

737

738

739

740

741

742

743

744

745

746

747

748

749

750

751

wave roses for Atlantic shorelines. (Source: NOAA's WAVEWATCH III global model; location $19 \mathrm{~N}$ and $65 \mathrm{~W}$ with a $1.0 \times 1.25$ degree grid resolution; Feb 1997-Sept 2010). Central panel shows hurricane tracks (1960-2017) within 100km of the BVI. Lower panel shows Caribbean wind and wave roses. (Source: NOAA Station ID: 42060; location 16N and 63W; April 2013-Oct. 2017).

Figure 8. Classification of beach planforms in the BVI.

Figure 9. Incipient tombolo at Sandy Spit. Panel A (May 2008) shows Green Cay and Sandy Spit with prevailing waves from the northeast. Panel B (July 2005) shows exposed beachrock.

Figure 10. Classification of BVI beaches based on nearshore/shoreface morphology.

Figure 11. Headland-attached linear reef at Oil Nut Bay, Virgin Gorda. From the beach to the reef crest is approximately $500 \mathrm{~m}$ or less and depth may be greater than $5 \mathrm{~m}$. Red arrow identifies the reef crest.

Figure 12. A terrace flat is a shallow, broad portion of the foreshore without a distinctive reef crest that extends no more than $500 \mathrm{~m}$ offshore. Low relief corals and seagrasses are common but the flat may also be composed only of sand. (Carrot Bay, Tortola). 
752 Figure 13. A graded reef lacks a prominent reef crest and slopes steeply to depths 753 greater than $20 \mathrm{~m}$ (North Thatch, Great Thatch).

754

755 Figure 14. 1). Banana Wharf, Beef Island - Linear barrier coral rubble beach. 1a is a 756 close-up of the pond in the upper right-hand corner of (1). 2) Tombolo formed between 757 Pelican Cay and Little Jost Van Dyke (Source: BVI Survey Department). 2a shows the 758 rubble accumulated between the two islands. 3) NW side of JVD and 3a, a close-up of 759 the beach and ridges.

760

761 Figure 15. Location and results of multivariate analysis on 70 sand beaches in the BVI 762 classified on mean carbonate content and mean grain sizes along the swash, mid and 763 berm zones of the beach.

764 